\title{
Chemo-profiling, Antioxidant Potential and Ionomic Analysis of Cichorium intybus L.
}

\author{
Bisma Malik', Tanveer Bilal Pirzadah', Inayatullah Tahir², Reiaz UI Rehman ${ }^{1 *}$
}

\section{Bisma Malik', Tanveer Bilal Pirzadah ${ }^{1}$, Inayatullah Tahir ${ }^{2}$, Reiaz UI Rehman ${ }^{1 *}$ 'Department of Bioresources, University of Kashmir, Srinagar, Jammu and Kashmir, INDIA. \\ ${ }^{2}$ Department of Botany, University of Kashmir, Srinagar, Jammu and Kashmir, INDIA.}

\section{Correspondence}

\section{Reiaz UI Rehman}

Assistant Professor, Department of Bioresources University of Kashmir, Srinagar, Jammu and Kashmir, INDIA.

Phone no: +91-9796546222

E-mail: rreiazbiores@gmail.com bisma767@gmail.com

\section{History}

- Submission Date: 12-06-2017;

- Review completed: 18-07-17;

- Accepted Date: 31-08-17

DOI : 10.5530/pj.2017.6.144

Article Available online http://www.phcogj.com/v9/i6

\section{Copyright}

(C) 2017 Phcog.Net. This is an openaccess article distributed under the terms of the Creative Commons Attribution 4.0 International license.

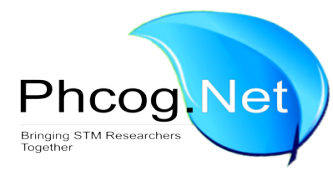

\begin{abstract}
Background: Cichorium intybus commonly called as chicory or coffee weed was traditionally used for the treatment of various ailments associated with liver, kidney and heart. The aim of the present study was phytochemical screening, in-vitro evaluation of antioxidant potential, element analysis of wild and cultivated chicory and GC-MS analysis of methanolic leaf extract of wild chicory grown in Kashmir Himalaya. Method: To achieve this goal, the qualitative and quantitative analysis was done to determine the antioxidant potential. Element analysis was done using AAS and metabolite fingerprinting was done using GC-MS to ascertain the presence of active phytoconstituents in chicory leaves. Results: The qualitative screening of leaf extracts from wild and cultivated chicory indicates the presence of important bioactive constituents. The leaf extract of wild chicory constituted the higher amount of total phenol and flavonoid contents and also showed strong radical scavenging activities of DPPH, SOD and hydrogen peroxide radical as indicated by lower values of $\mathrm{IC}_{50}$ compared to cultivated chicory. Furthermore, both extracts of wild chicory showed the highest total antioxidant potential for the reduction of $\mathrm{Fe}^{3+}$ to $\mathrm{Fe}^{2+}$ when compared with cultivated chicory. The results from the elemental analysis shows that leaf extract of wild chicory exhibits higher concentration of elements as compared to cultivated one, thus can be used as a potential bio-fortified crop. The GC-MS analysis determines the presence of 78 different compounds in the methanolic leaf extract of wild chicory. The major phytochemical constituents were phytol (7.96\%) and stigmat-5-en-3-ol (6.45\%). Conclusion: The findings of the present study suggested the therapeutic potential of chicory leaves; particularly wild chicory proves to be a potent source of natural antioxidant against free radical associated damages. Metabolite profiling study revealed important metabolites having potent pharmacological actions.
\end{abstract}

Key words: Cichorium intybus, Phytochemical Analysis, Antioxidant Activities, AAS, GC-MS.

\section{INTRODUCTION}

Reactive oxygen species (ROS) or free radicals are formed in the biological system as a result of biological oxidation. Their excessive generation results in oxidative stress. ${ }^{1}$ Which ultimately results in the DNA damage, lipid and protein degredation. ${ }^{2}$ In plant systems the ROS are formed as a result of biotic or abiotic stresses and they are sequestrated by internal defense system such as SOD (superoxide dismutase), CAT (catalase), and POD (peroxidase), glutathione system. ${ }^{3}$ Recently the information documented proposed that the free radicals or ROS such as $\mathrm{OH}$ (hydroxyl radical), $\mathrm{O}_{2}$. (superoxide radical anion) and $\mathrm{H}_{2} \mathrm{O}_{2}$ (hydrogen peroxide) contributes to several diseases and disorders. ${ }^{4}$ The use of chemically prepared antioxidants in food and pharmaceutical industry has become a matter of utmost concern among scientific community due to safety issues which has resulted in the development of interest in unraveling the sources of natural antioxidants. ${ }^{5}$ Many studies have suggested the replacement of synthetically prepared antioxidants by those derived from natural sources. ${ }^{6}$ According to WHO, a medicinal plant is the one which is having one or more plant parts containing important bioactive substances having pharmacological applications. ${ }^{7}$ Currently, medicinal plants provide many novel sources of drugs and pharmaceutical products. Large amounts of bioactive substances (metabolites) such as polyphenols, terpenoids, vitamins, alkaloids, coumarins etc. have received a lot of attention world-wide as an alternative source of therapeutic agents against various oxidative stress related diseases. ${ }^{8}$ It is the need of the hour that the natural sources of drugs and pharmaceutical products from the medicinal plants should be identified, isolated and characterized for their medicinal properties as many populations around the world are still using traditional system of medicines. ${ }^{9}$ Cichorium intybus a perennial plant belongs to the Asteraceae family and the Cichorium genus comprises six species which are mainly distributed and used in traditional system of medicine throughout Asia and Europe. Cichorium intybus is a traditional plant used as food and medicinal crop in temperate parts of the old world that finds its application in food 
and pharmaceutical industries ${ }^{10,11}$ as carminative and against cardiac ailments. ${ }^{12}$ Chicory is found to be effective in jaundice, asthma, gout and rheumatic complaints. ${ }^{13}$ Chicory also Possesses anti-cancer ${ }^{14}$ anti-fungal and anti-malarial ${ }^{15}$ anti-diabetic ${ }^{16}$ and free radical scavenging ${ }^{17}$ activity. When added to coffee, it neutralizes caffeine and helps in digestion and also enhances the flavor. ${ }^{18}$ Inulin from root is being used as a substrate of fibre in health and functional foods. ${ }^{19}$ Inulin used as prebiotic helps in inhibiting gastrointestinal infection and boosts the immune system. ${ }^{20}$ In Europe, it has been consumed for centuries as a leafy vegetable and it is nowadays ranked as a functional vegetable of the 21 st century. ${ }^{21}$ Besides, being popularly cultivated and used widely, there are no reports of phytochemical analysis and antioxidant potential of chicory grown in Kashmir Himalaya. It is in this perspective that the current work is aimed to determine the qualitative screening of phytochemicals, antioxidant potential and mineral element analysis of methanolic and ethanolic leaf extract of wild and cultivated chicory was done by Atomic Absorption Spectrophotometry (AAS) followed by Gas ChromatographyMass Spectrum (GC-MS) analysis of methanolic leaf extract of wild chicory to identify the phytoconstituents present in chicory.

\section{MATERIAL AND METHODS}

\section{Chemical reagents}

All solvents were of analytical grade purchased from Merck (Germany) and all the standard chemicals like DPPH (Diphenyl-2-picrylhydrazyl), TPTZ (2,4,6-tri[2-pyridyl]-s-triazine), Ascorbic acid, Ferrous sulphate, TBA (Thiobarbutaric acid), Rutin, Gallic acid, NBT (Nitroblue tetrazolium), PMS (phenazine methosulphate), NADH (Nicotinamide Adenine dinucleotide), Riboflavin, TCA (Trichloroacetic acid) were purchased from Sigma Aldrich (USA). All other reagents and unlabelled chemicals were of analytical grade and used without further purification.

\section{Plant material}

Cichorium intybus L. (chicory) seeds were procured from herbal garden of Hamdard University, New Delhi and cultivated in Kashmir University Botanical Garden (KUBG) and the wild plant material was collected from Bandipora district of Kashmir identified by the Center for Biodiversity and Taxonomy, University of Kashmir, Hazratbal, Srinagar.

\section{Collection of plant Material}

Healthy and fresh leaves of wild and cultivated chicory at pre-flowering stage were collected and washed gently with distilled water (without squeezing) to remove debris and dust particles. The plant material is shade-dried at room temperature for 15 days and pulverized into a uniform material using a surface sterilized mortar and pestle which was further used for extraction.

\section{Solvent extraction procedure}

The method of Okogun $(2000)^{22}$ was used to obtain the plant extracts with slight modifications. Five grams $(5 \mathrm{~g})$ of dried plant material were soaked in $50 \mathrm{ml}$ of respective solvents viz $80 \%$ ethanol and $80 \%$ methanol. The leaves were immersed completely and then covered with aluminium foil. Extraction was allowed to continue for $48 \mathrm{~h}$ by keeping it on a rotary shaker (80rpm). The extract was filtered using muslin cloth and the final extract was obtained by evaporating the solvent at room temperature $\left(28 \pm 2^{\circ} \mathrm{C}\right)$. The air dried extract was then stored at $4^{\circ} \mathrm{C}$ in pre sterilized air tight flasks.

\section{Qualitative phytochemical screening}

The dried methanolic and ethanolic leaf extract of wild and cultivated chicory was used for qualitative analysis. The occurrence of different phyto-chemicals like phenols, flavonoids, alkaloids, tannins, phlobatannins, coumarins, saponins, antraquinones, steroids, terpenoids and cardiac glycosides was confirmed individually by standard procedures given by Shabbir et al. (2013). ${ }^{23}$

\section{Quantitative physio-chemical assays \\ Estimation of Total Phenolic Content (TPC)}

The TPC was estimated by Folin-Ciocalteau (FC) reagent protocol ${ }^{24}$ with slight modifications using Gallic acid as a standard phenol compound. The results were expressed as milligram of Gallic acid equivalent (GAE) per gram weight of the extract (mg/g) (five calibration points, concentration in the range of $\left.10-100 \mathrm{mg} / \mathrm{ml}, \mathrm{R}^{2}=0.999\right)$.

\section{Estimation of TFC (Total Flavonoid Content)}

TFCs were investigated by a protocol described by Sakanaka et al. $(2005)^{25}$ with slight modification using rutin as a standard flavonoid compound. TFC of the reaction mixture was determined from the standard curve of rutin $(\mathrm{mg} / \mathrm{ml})$ and was expressed as equivalent to rutin in $\mathrm{mg} / \mathrm{g}$ of the extract weight (five calibration points, concentration in the range of $\left.10-100 \mathrm{mg} / \mathrm{ml}, \mathrm{R}^{2}=0.999\right)$.

\section{Evaluation of antioxidant assays Total reducing power}

The reducing ability of the extracts was ascertained by employing the protocol of Yen and Duh (1993). ${ }^{26}$ In this assay the capability of the extract to reduce $\mathrm{Fe}^{3+}$ to $\mathrm{Fe}^{2+}$ was determined. Methanolic and ethanolic extracts of various concentrations $(0.1-0.5 \mathrm{mg} / \mathrm{ml})$ were mixed with $20 \mathrm{mM}$ phosphate buffer $(500 \mu \mathrm{L})$ with $\mathrm{pH} 6.6$ and $500 \mu \mathrm{L}$ of $1 \% \mathrm{~K}_{3}\left[\mathrm{Fe}(\mathrm{CN})_{6}\right]$ (potassium ferricyanide), and incubated at $50{ }^{\circ} \mathrm{C}$ for 20 mins. To this solution, $500 \mu \mathrm{L}$ of trichloroacetic acid (10\%) was added to stop the reaction and centrifuged for $10 \mathrm{~min}$ at $2500 \mathrm{rpm}$. The volume was made with $\mathrm{ddH}_{2} \mathrm{O}(2.9 \mathrm{ml})$ and $0.1 \% \mathrm{FeCl}_{3}(500 \mu \mathrm{L})$ was then added and the absorbance at $700 \mathrm{~nm}$ of the reaction solution was recorded. Increase in absorbance of the reaction solution interpreted increasing reducing power. Ascorbic acid was used as the standard.

\section{Ferric Reducing Antioxidant Potential - FRAP assay}

A method of Benzie and Strain (1996) ${ }^{27}$ with slight modifications was followed for the determination of FRAP activity of the plant extracts which was based on blue color formation by the reduction of the ferric to ferrous form. Antioxidants act as reducing agent in FRAP assay which is oxidation-reduction reaction linked-colorimetric method, which employs an easy system of reduced oxidant present in stoichiometric excess. The plant extracts react for $30 \mathrm{~min}$ with the FRAP solution in dark and the absorbance of the reaction solution was then read at $593 \mathrm{~nm}$ and the reducing power of each sample was calculated from the standard curve of $\mathrm{Fe}_{2} \mathrm{SO}_{4}$. Results were expressed in $\mu \mathrm{M} \mathrm{Fe}$ (II)/g dry mass (five calibration points, concentration in the range of $10-50 \mathrm{mg} / \mathrm{ml}, \mathrm{R}^{2}=0.9991$ ).

\section{Diphenyl-2-picrylhydrazyl (DPPH) free radical scavenging activity}

The antioxidant capability of the samples were estimated by ascertaining the free radical scavenging or the hydrogen donating ability of the stable DPPH (1, 1-diphenyl-2-picrylhydrazyl) free radical according to the modified method described by Braca et al. (2003). ${ }^{28}$ BHT was used as the standard and the percentage inhibition was calculated by using the formula:

$$
\% \text { inhibition }=\left[\left(\mathrm{A}_{0}-\mathrm{A}_{1}\right) / \mathrm{A}_{0}\right] \times 100
$$

Where $\mathrm{A}_{0}$ - control absorbance and $\mathrm{A}_{1}$ - sample absorbance.

\section{Superoxide radical scavenging activity}

Superoxide radical scavenging activity of the various plant extracts was determined according to the detailed method of Fontana et al. (2001). ${ }^{29}$ In this assay NADH is oxidized in PMS-NADH (Phenazine 
Methosulfate-Nicotinamide Adenine Dinucleotide) system which is assayed by the reduction of NBT (Nitroblue tetrazolium) to a purple formazan generating the superoxide radical. Ascorbic acid was used as a standard and the percent inhibition of superoxide radical produced was calculated using the following formula:

$$
\% \text { Scavenging }=\left[\left(\mathrm{A}_{0}-\mathrm{A}_{1}\right) / \mathrm{A}_{0}\right] \times 100
$$

Where $\mathrm{A}_{0}$-control absorbance and $\mathrm{A}_{1}$-sample absorbance.

\section{Hydrogen peroxide radical scavenging activity}

The scavenging activity of the various extracts towards hydrogen peroxide radicals was estimated by the modified method of Nabavi et al. (2008). ${ }^{30}$ Ascorbic acid was used as the standard. Hydrogen peroxide inhibition percentage was calculated by using the following formula.

$$
\text { \%age of inhibition }=\left[\left(\mathrm{A}_{0}-\mathrm{A}_{1}\right) / \mathrm{A}_{0}\right] \times 100
$$

Where $\mathrm{A}_{0}$-control absorbance and $\mathrm{A}_{1}$-sample absorbance.

\section{Mineral element analysis}

Mineral elemental analysis of Wild and Cultivated Cichorium intybus L. (Chicory) was done by atomic absorption spectrophotometry (AAS) (Perkin-Elmer Analyst 100, Waltham, MA, USA) according to the method of Mostofa et al. (2015). ${ }^{31} 0.25$ gm of ground dried plant material was weighed and acid digested in the ratio of $\mathrm{HNO}_{3}: \mathrm{H}_{2} \mathrm{SO}_{4}: \mathrm{HCl}(5: 1$ : $0.5)$. Solution was boiled in fume-hood on hot plate till digestion has been completed (indicated by white fumes coming out from the flask). Add few drops of $\mathrm{ddH}_{2} \mathrm{O}$ and allow the solution to cool. Digested samples were centrifuged and then final volume was made $50 \mathrm{ml}$ with $\mathrm{ddH}_{2} \mathrm{O}$.

\section{Metabolite profiling \\ Sample preparation for Gas Chromatography-Mass Spectrum analysis}

The $0.2 \mathrm{~g}$ of dried extract powder of Cichorium intybus L. (Chicory) leaf sample was dissolved in $10 \mathrm{ml}$ of methanol solvent properly mixed and kept for 72 hours, then filtered through $0.45 \mu \mathrm{m}$ syringe filter (Millipore Corp., Bedford, MA, USA). $1 \mu \mathrm{l}$ aliquot of the sample was then injected into the GC-MS port for the metabolite analysis (Shimadzu QP-2010 Plus with Thermal Desorption System TD 20). GC-MS analysis of methanolic leaf extract of wild chicory was determined according to the method of Roessner et al., (2000). ${ }^{32}$ Identification of the mass spectrum GC-MS was done by using NIST (National Institute Standard and Technology) library having more than 62000 patterns. By using these libraries, the spectrum of the unknown compound was compared to the spectrum of known compound stored in NIST library. The name of the compound, molecular weight, chemical formula and structure of the test sample were ascertained.

\section{Statistical analysis}

The experimental data were expressed as mean \pm standard deviation (SD) of three replicates. The results were analysed by using analysis of variance (ANOVA) and the antioxidant potential of various assays was determined as $\mathrm{IC}_{50}$ values by using Graph pad prism 5-software. Results were regarded as statistically significant at $\mathrm{p} \leq 0.05$.

\section{RESULTS AND DISCUSSION}

\section{Qualitative phytochemical screening}

The phytochemical analysis of methanolic and ethanolic leaf extracts of wild and cultivated chicory was screened for the presence of various bioactive compounds. Specific qualitative tests were performed to identify compounds of pharmacological importance through standard methods. In the present study, the analysis of leaf extract of wild chicory indicates the occurrence of phenols, flavonoids, alkaloids, coumarins, anthraquinones, cardiac glycosides, saponins in most prominent amounts while tannins and phlobatannins in less amount. Similarly the analysis of leaf extract of cultivated chicory revealed the presence of phenols, flavonoids, alkaloids, anthraquinones, cardiac glycosides, coumarins, saponins present in moderate amounts while as tannins, phlobatannins present in less amounts when compared to wild chicory. These results were documented in (Table 1). Thus, the wild chicory was found to be richer in phytochemicals as compared to cultivated species. Previous reports indicate that the activities as well as phytochemical composition in plants were affected by many factors such as cultivars, maturity, environmental factors, color as well as types and quantity of phytochemicals. ${ }^{33}$ It has also been considered that plants and their phytochemical extracts holds great assurance to be used in future medicines as they contain possible sources of antiviral, anti-tumoral and anti-microbial agents. ${ }^{34,35}$ Polyphenols were found to be important for research and gains a lot of attention since they were found more effective on human health. ${ }^{36}$ Polyphenols and flavonoids are responsible for prevention of various diseases caused by free radicals. ${ }^{37}$ Phenolics act as terminators of free radicals from oxidation reaction while as flavonoids are responsible for radical scavenging effects. ${ }^{38}$

\section{Estimation of total phenol content (TPC) and total flavonoid content (TFC)}

In the present study, the comparison of methanolic and ethanolic leaf extracts of wild and cultivated chicory was done. From the analysis of total phenolic content, it was found that the methanolic leaf extract of wild chicory exhibits the maximum amount of TPC $(25.93 \pm 0.20 \mathrm{mg} / \mathrm{g}$ GAE) followed by ethanolic leaf extract $(21.01 \pm 0.47 \mathrm{mg} / \mathrm{g} \mathrm{GAE})$ while as, TPC was $19.21 \pm 0.60 \mathrm{mg} / \mathrm{g}$ GAE in methanolic leaf extract and $16.98 \pm 0.45 \mathrm{mg} / \mathrm{g}$ GAE in ethanolic leaf extract of cultivated chicory. In case of TFC, the methanolic leaf extract of wild chicory exhibited the highest TFC $(13.5 \pm 0.70 \mathrm{mg} / \mathrm{g} \mathrm{RE})$ followed by ethanolic leaf extract $(8.49 \pm 0.08 \mathrm{mg} / \mathrm{g} \mathrm{RE})$ while as it was $9.51 \pm 0.43 \mathrm{mg} / \mathrm{g} \mathrm{RE}$ in methanolic leaf extract and $7.78 \pm 0.17 \mathrm{mg} / \mathrm{g} \mathrm{RE}$ in ethanolic leaf extract of cultivated chicory (Table 2 ). It was evident from the results that the TPC and TFC of wild and cultivated chicory followed a similar trend, however the highest phenols and flavonoid were found in methanolic leaf extract of wild chicory. The plants which have high medicinal value exhibits high amount of phenolics or polyphenols constituting the plant secondary metabolites. It has been known that phenolic compounds are strong antioxidants as they terminate the radical chain reactions ${ }^{39}$ because of the presence of important chemical constituents that attribute towards their scavenging activity and contribute directly to their anti-oxidative action. ${ }^{40}$ Furthermore, flavonoids are responsible for the radical scavenging effects of most medicinal plants through scavenging or chelating process in-vivo as well as in-vitro. ${ }^{41}$ In Europe, chicory is being eaten as leafy vegetables for centuries as it contains important secondary metabolites (phenols, flavonoids, polyamines etc.). ${ }^{17}$ In our study the quantitative estimation of total phenols and flavonoid content indicates that the methanolic leaf extract possesses the highest concentration of TPC and TFC. Similar findings have been reported in Carissa opaca fruits, ${ }^{42}$ Rumex hastatus D. Don leaves ${ }^{43}$ and in Mentha species. ${ }^{44}$ Therefore, the antioxidant activity of an extract is directly proportional to its TPC which is due to the presence of the substituted 5,7,3', $4^{\prime}$-hydroxy flavonoids which are possibly found to exhibit free radical scavenging activity. ${ }^{45,46}$ Our study also reveals that the TPC and TFC of wild chicory were higher than the cultivated chicory. Several researchers have also reported that there are significant differences in TPC and TFC when different or same varieties and cultivars were studied at different environments. ${ }^{47}$ Thus the plants rich in phenols and flavonoids might be a good source of remedial potential against the oxidative stress. ${ }^{48}$ 
Table 1: Comparative qualitative phytochemical screening of $80 \%$ methanolic and ethanolic leaf extract of wild and cultivated Cichorium intybus L. (chicory)

\begin{tabular}{|c|c|c|c|c|}
\hline \multirow[t]{2}{*}{ Phytochemical tests } & \multicolumn{2}{|c|}{ Methanolic } & \multicolumn{2}{|c|}{ Ethanolic } \\
\hline & Wild-Type & Cultivated-Type & Wild-Type & Cultivated-Type \\
\hline Alkaloids & +++ & ++ & +++ & ++ \\
\hline Anthraquinones & +++ & ++ & +++ & ++ \\
\hline Cardiac glycosides & +++ & ++ & +++ & ++ \\
\hline Coumarins & +++ & ++ & +++ & ++ \\
\hline Flavonoids & +++ & +++ & +++ & +++ \\
\hline Saponins & +++ & ++ & +++ & ++ \\
\hline Phlobatannins & ++ & + & ++ & + \\
\hline Tannins & +++ & ++ & +++ & ++ \\
\hline Terpenoids & ++ & +++ & ++ & +++ \\
\hline Phenols & +++ & +++ & +++ & +++ \\
\hline
\end{tabular}

Table 2: A comparison of total phenolic and flavonoid content of wild and cultivated Cichorium intybus L. (chicory)

\begin{tabular}{cccccc}
\hline & & \multicolumn{2}{c}{$\begin{array}{c}\text { Phenolic content } \\
\text { GAE (mg/g) }\end{array}$} & \multicolumn{2}{c}{$\begin{array}{c}\text { Flavonoid content } \\
\text { RE (mg/g) }\end{array}$} \\
\hline Solvent extract & Concentration $(\mathrm{ml})$ & Wild chicory & Cultivated chicory & Wild chicory & Cultivated chicory \\
$80 \%$ Methanol & 0.1 & $25.93 \pm 0.20$ & $19.21 \pm 0.60$ & $13.5 \pm 0.70$ & $9.51 \pm 0.43$ \\
$80 \%$ Ethanol & 0.1 & $21.01 \pm 0.47$ & $16.98 \pm 0.45$ & $8.49 \pm 0.08$ & $7.78 \pm 0.17$ \\
\hline
\end{tabular}

Data are expressed as means \pm standard deviation $(n=3)$.

Data is significant at $\mathrm{p} \leq 0.05$

GAE: gallic acid equivalents

RE: Rutin equivalents

+++ Strongly present, ++ moderately present and + less present

\section{Total reducing power}

Reducing power ability is correlated with the antioxidant ability of the plant extract which may act as a considerable indicator of the antioxidant activity. In this method, ferric cyanide complex (electron donor) is reduced to ferrous form, indicating the presence of reductants in the sample extracts. In our study, it was observed that the reducing ability of both the leaf extracts increases significantly with increase in concentration. The reducing power of the methanolic leaf extract of wild chicory exhibited a strong reducing activity of $0.674 \pm 0.002 \mu \mathrm{g} / \mathrm{ml}$ followed by ethanolic leaf extract of $0.541 \pm 0.002 \mu \mathrm{g} / \mathrm{ml}$ while as it was $0.486 \pm 0.002 \mu \mathrm{g} / \mathrm{ml}$ in methanolic leaf extract and $0.446 \pm 0.002 \mu \mathrm{g} / \mathrm{ml}$ in ethanolic leaf extract of cultivated chicory (Figure 1a). The data also revealed that the reducing power of both the leaf extract of wild chicory was better than the cultivated one. In plants reducing power assay has been considered as one of the most important indicator of antioxidant activity. ${ }^{49}$ The presence of reductones in the plant extract is commonly correlated with its reducing capabilities as reductones have shown the antioxidant action by terminating the radical chain reaction as they donates hydrogen atom in the reaction mixture..$^{50}$ In our study, it has been observed that the total reduction ability of converting $\mathrm{Fe}^{3+}$ to $\mathrm{Fe}^{2+}$ in presence of both the extracts increases in a concentration dependent manner suggesting that both the extracts donates an electron in the reaction mixture which reacts with free radicals breaking down the chain reaction and transform them into much stable non-radical products. However, methanolic leaf extract exhibited the highest reducing power than the ethanolic leaf extract in wild and cultivated chicory. Similar observations were also reported in methanolic leaf extracts of Sonchus asper L. ${ }^{23}$ and Dolichandrone atrovirens. ${ }^{51}$

\section{FRAP assay}

Ferric reducing antioxidant power (FRAP) assay was employed to determine the total antioxidant activity of the plant extract. In this assay, redox reaction takes place which reduces ferric III to ferrous II by donating an electron in presence of antioxidants present in the sample. In the present study, the trend for ferric ion reducing activities of methanolic and ethanolic leaf extracts of wild and cultivated chicory are shown in Figure $1 \mathrm{~b}$. The methanolic and ethanolic leaf extract of wild and cultivated chicory showed increased ferric reducing antioxidant power in a concentration-dependent response. Among the extract tested, the FRAP value of methanolic leaf extract of wild chicory was found to be higher $(1254 \pm 0.002 \mu \mathrm{M} \mathrm{Fe} \mathrm{II/g} \mathrm{DW)} \mathrm{as} \mathrm{compared} \mathrm{to} \mathrm{ethanolic} \mathrm{leaf} \mathrm{extract}$ $(1049.73 \pm 0.002 \mu \mathrm{M} \mathrm{Fe} \mathrm{II/g} \mathrm{DW).} \mathrm{The} \mathrm{cultivated} \mathrm{chicory} \mathrm{follows} \mathrm{the}$ same trend with a FRAP value of $856.8 \pm 0.002 \mu \mathrm{M} \mathrm{Fe} \mathrm{II/g} \mathrm{DW} \mathrm{for}$ methanolic leaf extract and $803.1 \pm 0.001 \mu \mathrm{M}$ Fe II/g DW for ethanolic leaf extract. This data indicates that the wild chicory showed significantly a higher ferric reducing ability when compared to cultivated chicory. Similar observation was found in wild and cultivated species of strawberry. ${ }^{52}$ FRAP assay particularly estimates antioxidant or reductant present in a sample extract that reacts with ferric tripyridyltriazine $\left(\mathrm{Fe}^{3+}-\right.$ TPTZ) complex and forms a dark blue colored complex of ferrous tripyridyltriazine ( $\mathrm{Fe}^{2+}$ - TPTZ). ${ }^{27}$ Generally the antioxidants exhibited redox properties because they act as reductants, donors of hydrogen atom and singlet oxygen scavengers. ${ }^{53}$ Thus there is a reduction of Fe III TPTZ complex by antioxidants. ${ }^{54}$ In the present study, it has been observed that the FRAP values were higher in methanolic leaf extract compared to ethanolic extract. This showed that the methanolic extract was more efficient in extracting antioxidant in plant material as compared to 


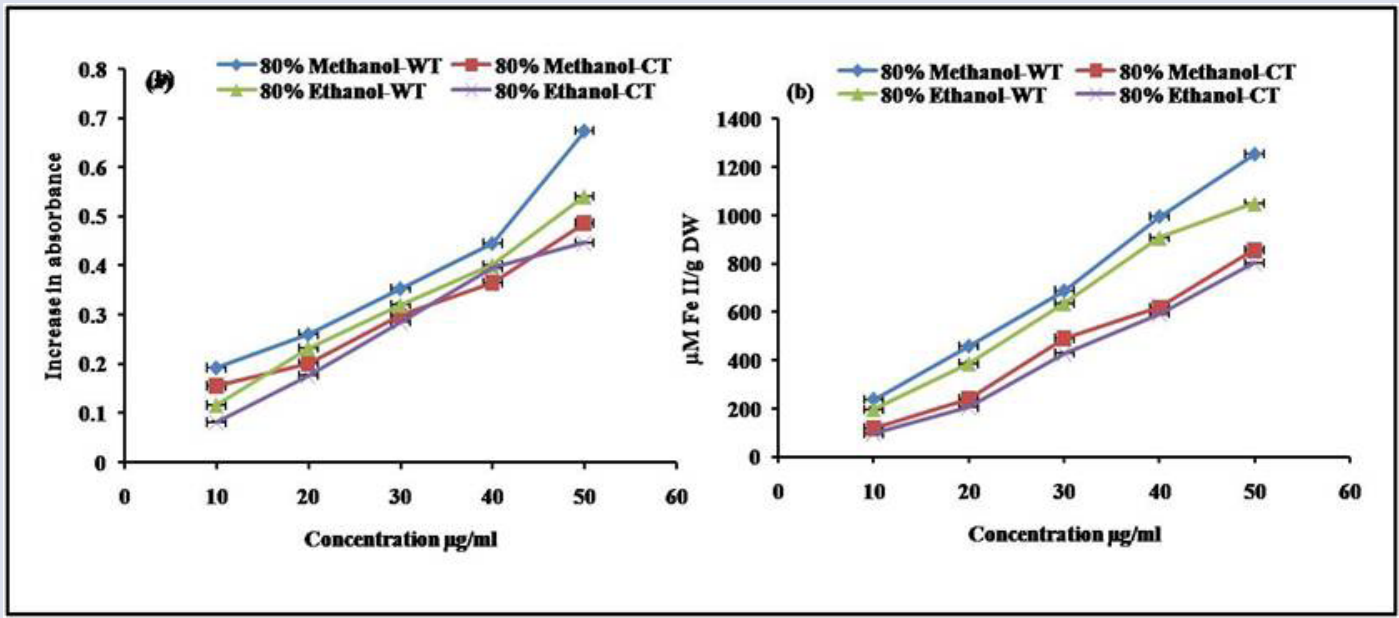

Figure 1: (a) Reducing power and (b) Total antioxidant activity (FRAP) of wild and cultivated Cichorium intybus L. (chicory) at different concentrations $(\mu \mathrm{g} / \mathrm{ml})$ of $80 \%$ methanolic and ethanolic leaf extracts respectively. Data represents mean \pm SE $(n=3)$. Significant at $P<0.05$

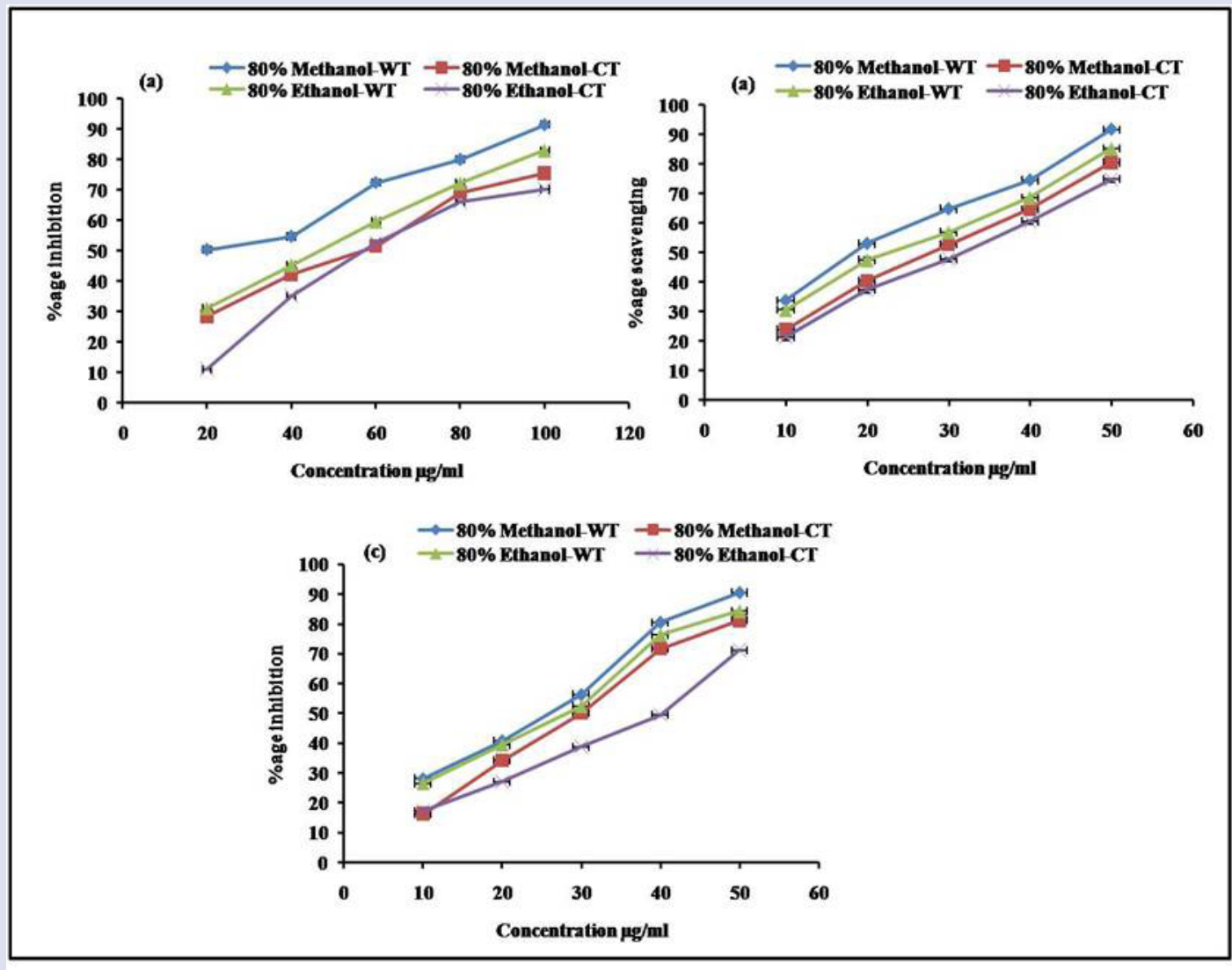

Figure 2: (a) DPPH activity, (b) Superoxide radical scavenging activity and (c) Hydrogen peroxide radical scavenging activity of wild and cultivated Cichorium intybus L. (chicory) at different concentrations $(\mu \mathrm{g} / \mathrm{ml})$ of $80 \%$ methanolic and ethanolic leaf extracts and data represents mean $\pm S E(n=3)$. Significant at $P<0.05$ 
Table 3: $\mathrm{IC}_{50}$ values of DPPH, superoxide radical scavenging and hydrogen peroxide radical scavenging of wild and cultivated Cichorium intybus L. (chicory) was calculated from linear regression plot

\begin{tabular}{ccccc}
\hline Antioxidant assays & \multicolumn{2}{c}{$\begin{array}{c}I_{50} \text { Values }(\mu \mathrm{g} / \mathrm{ml}) \\
\text { Methanolic Extract }\end{array}$} & \multicolumn{2}{c}{ Ethanolic Extract } \\
& Wild chicory & Cultivated chicory & Wild chicory & Cultivated chicory \\
\hline DPPH & $23.39 \pm 0.10$ & $46.81 \pm 0.60$ & $26.89 \pm 0.10$ & $48.08 \pm 0.20$ \\
Superoxide radical scavenging assay & $20.20 \pm 0.20$ & $25.02 \pm 0.14$ & $23.25 \pm 0.30$ & $29.16 \pm 0.10$ \\
Hydrogen peroxide radical & $24.45 \pm 0.17$ & $28.27 \pm 0.01$ & $26.22 \pm 0.40$ & $37.14 \pm 0.10$ \\
scavenging assay & & & & \\
\hline
\end{tabular}

Data are expressed as means \pm standard deviation $(n=3)$.

Data is significant at $\mathrm{p} \leq 0.05$

ethanol. Similar observations have been reported in Garcinia atrovirdis and Cynometra cauliflora. ${ }^{55}$ The ferric reducing antioxidant potential of both the extracts increased in a concentration-dependent response depicting a potent ferric reducing ability of wild and cultivated chicory. A similar observation was also reported in Samac (Rhus. coriaria L.) which shows an increase in ferric reducing power ability as the concentration increases. ${ }^{56}$ Furthermore, FRAP is easy to reproduce and directly correlated to the molar concentrations of the antioxidants present, thus from the present study it can be suggested that both the extracts of Cichorium intybus L. (chicory) may function as scavengers of free radicals by converting reactive free radical species into more stable non-reactive species. High level of antioxidant activity obtained for wild chicory could be due to its high level of polyphenols.

\section{DPPH radical scavenging activity}

For the screening of antioxidant activity of plant extracts, DPPH is one of the most widely used method. DPPH radical scavenging activities of methanolic and ethanolic leaf extracts of wild and cultivated chicory on the basis of percent inhibition is depicted in Figure 2a. In this study both the methanolic and ethanolic leaf extracts of wild and cultivated chicory showed dose-dependent response. Among the extracts tested, the methanolic leaf extract of wild chicory possesses the highest scavenging activity $\left(91.55 \%\right.$ with lowest $\mathrm{IC}_{50}$ value of $23.39 \mathrm{mg} / \mathrm{ml} \pm 0.003$ ) followed by ethanolic leaf extract $\left(83.35 \%\right.$ with $\mathrm{IC}_{50}$ value of $26.89 \mathrm{mg}$ / $\mathrm{ml} \pm 0.04)$. The result also revealed that the cultivated chicory follows the same trend with a scavenging activity of $75.65 \%$ with $\mathrm{IC}_{50}$ value of 46.81 $\mathrm{mg} / \mathrm{ml} \pm 0.20$ and $70.25 \%$ with $\mathrm{IC}_{50}$ value of $48.08 \mathrm{mg} / \mathrm{ml} \pm 0.10$ for ethanolic leaf extract. The $\mathrm{IC}_{50}$ value of various extracts is shown in (Table 3). This study shows that the tested leaf extracts have the capability of donating a proton and could act as a free radical scavengers or inhibitors, which possibly serves as primary antioxidants. The reactivity of methanolic and ethanolic leaf extracts of wild and cultivated chicory was analyzed with DPPH and its color shows characteristics absorption at wavelength $517 \mathrm{~nm} .{ }^{57}$ In the present study, it was observed that the methanolic leaf extracts constituted the maximum DPPH scavenging activity as compared to ethanolic leaf extract. Similar observations were found in the methanolic leaf extracts of Maytenus royleanus ${ }^{23}$ and Mentha species ${ }^{44}$ and also in methanolic root extract of Erythrina Indica ${ }^{58}$ indicating the presence of free radical scavengers which function potentially as principle antioxidants. Further, the results also revealed that the wild chicory shows higher DPPH free radical scavenging ability with the lowest $\mathrm{IC}_{50}$ value as compared to cultivated chicory. Similar observations were also found in wild and cultivated species of strawberry (Fragaria vesca L. $)^{52}$ and Cyclamen persicum, Urtica pilulifera and Malva sylvestris. ${ }^{59}$ The $\mathrm{IC}_{50}$ value of DPPH scavenging capacity is concentration of sample that can inhibit $50 \%$ of DPPH radicals. ${ }^{60}$ Therefore, the $\mathrm{IC}_{50}$ value is inversely proportional to the antioxidant capacity of the extract. ${ }^{61}$

\section{Superoxide radical scavenging activity}

PMS-NADH oxidation reaction system generates the superoxide radicals $\left(\mathrm{O}_{2}{ }^{-}\right)$which can be estimated by their capability to reduce NBT. In the presence of the plant extracts, the absorbance at 560 $\mathrm{nm}$ deceases indicating the capability of plant extracts to scavenge the superoxide radicals present in the reaction mixture. In the present study, it was found that the superoxide radical scavenging activities of both methanolic and ethanolic leaf extract of wild and cultivated chicory showed dose-dependent response (Figure 2b). Methanolic leaf extract of wild chicory showed a scavenging activity of $91.55 \%$ with $\mathrm{IC}_{50}$ value of $20.20 \mathrm{mg} / \mathrm{ml} \pm 0.03$ followed by ethanolic leaf extract having scavenging activity of $89.17 \%$ with $\mathrm{IC}_{50}$ value of $23.25 \pm 0.03$. The results also revealed that the cultivated chicory in both the extracts follows the same trend. The scavenging activity of methanolic leaf extract of cultivated chicory was found to be $82.43 \%$ with $\mathrm{IC}_{50}$ value of $25.02 \mathrm{mg} / \mathrm{ml} \pm 0.01$ followed by ethanolic leaf extract having scavenging activity of $78.78 \%$ with $\mathrm{IC}_{50}$ value of $29.16 \mathrm{mg} / \mathrm{ml} \pm 0.02$ (Table 3 ). The results obtained emphasized the ability of Cichorium intybus L. (chicory) extracts to quench the superoxide anion produced through PMS-NADH-NBT system. The generation and scavenging of superoxide anion free radicals are evolved in PMS-NADH-NBT system, in which the absorbance decreases at $560 \mathrm{~nm}$ in presence of antioxidants ${ }^{62}$ indicating the sequestration of superoxide anions in the reaction solution following the increase in superoxide free radical scavenging ability in a dose-dependent response. Superoxide radical scavenging activity of methanolic and ethanolic leaf extracts of wild and cultivated chicory was elevated in a concentration-dependent manner in the present study. Low levels of $\mathrm{IC}_{50}$ value indicates that the phytochemicals present in methanolic and ethanolic extracts are powerful quenchers of superoxide radicals at lower concentrations.

\section{Hydrogen peroxide radical scavenging activity}

Hydrogen peroxide $\left(\mathrm{H}_{2} \mathrm{O}_{2}\right)$ in excess inside the cell system results in the formation of very reactive molecules such as $\mathrm{OH}$ radical which can further react with metals like $\mathrm{Fe}^{2+}$ or $\mathrm{Cu}^{2+}$ and $\mathrm{O}_{2}^{--}$in a Haber-Weiss reaction but $\mathrm{H}_{2} \mathrm{O}_{2}$ itself is not very reactive. Therefore annihilating of excess production of $\mathrm{H}_{2} \mathrm{O}_{2}$ is very important from the cells or food system. The hydrogen peroxide radical scavenging ability ascertained in this study for the methanolic and ethanolic leaf extract of Cichorium Intybus $\mathrm{L}$. (chicory) were able to scavenge $\mathrm{H}_{2} \mathrm{O}_{2}$ in a dose-dependent manner (10-50 $\mu \mathrm{g} / \mathrm{ml}$ ) (Figure $2 \mathrm{c}$ ). Among the extracts tested, the methanolic leaf extract of wild chicory had the highest scavenging activity of $90.41 \%$ with $\mathrm{IC}_{50}$ value of $24.45 \mathrm{mg} / \mathrm{ml} \pm 0.04$ followed by ethanolic leaf extract having a scavenging activity of $84.31 \%$ with $\mathrm{IC}_{50}$ value of $26.22 \mathrm{mg} / \mathrm{ml} \pm 0.20$. The result also indicates that the cultivated chicory follows the same trend as that of wild chicory. The values of hydrogen peroxide scavenging ability of cultivated chicory in methanolic leaf extract were found to be $81.24 \%$ with $\mathrm{IC}_{50}$ value of $28.27 \mathrm{mg} / \mathrm{ml} \pm 0.04$ 
Table 4: Mineral element analysis of leaf extract of wild and cultivated Cichorium intybus L. (chicory) by AAS

\begin{tabular}{ccc}
\hline Element & Wild-Type (ppm) & Cultivated-Type (ppm) \\
\hline $\mathrm{Ca}$ & $29876 \pm 20.00$ & $21430 \pm 25.30$ \\
$\mathrm{Fe}$ & $1478 \pm 15.75$ & $1250 \pm 15.60$ \\
$\mathrm{Al}$ & $756 \pm 13.80$ & $637.5 \pm 14.50$ \\
$\mathrm{Mn}$ & $321 \pm 10.33$ & $152.25 \pm 9.50$ \\
$\mathrm{Zn}$ & $244.98 \pm 10.30$ & $140.75 \pm 12.2$ \\
$\mathrm{Ni}$ & $112.98 \pm 8.78$ & $95.75 \pm 11.05$ \\
$\mathrm{Cu}$ & $59 \pm 7.87$ & $43 \pm 10.30$ \\
$\mathrm{Cd}$ & $32.78 \pm 5.89$ & $22.25 \pm 5.07$ \\
$\mathrm{~Pb}$ & $14.5 \pm 2.36$ & $5.7 \pm 0.3$ \\
$\mathrm{Co}$ & $10.67 \pm 3.2$ & $3.25 \pm 1.2$ \\
$\mathrm{Cr}$ & $4.56 \pm 1.5$ & $2.67 \pm 0.3$ \\
\hline
\end{tabular}

Data are expressed as means \pm standard deviation $(n=3)$. Data is significant at $\mathrm{p} \leq 0.05$

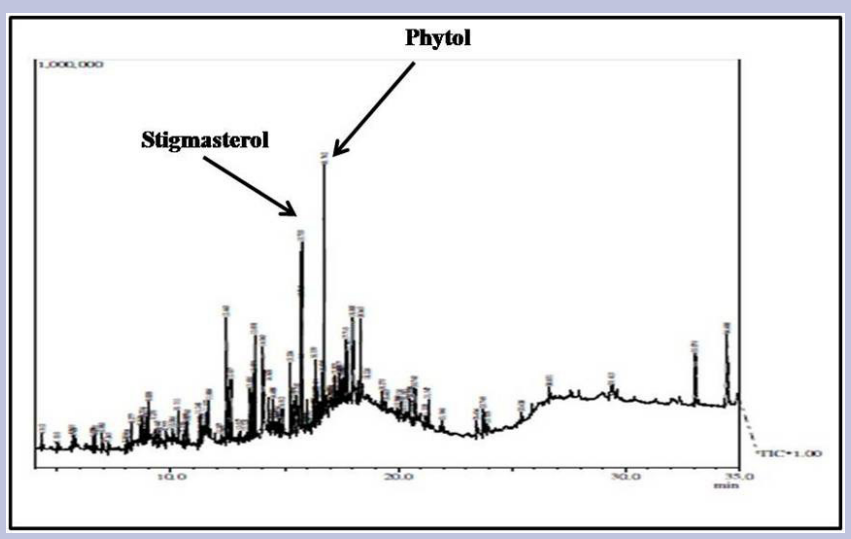

Figure 3: Shows the total ion chromatogram of methanolic leaf extract of wild chicory sample; about 98 peaks were detected. The detected peaks were identified using the NIST library.

and $71.17 \%$ with $\mathrm{IC}_{50}$ value of $37.14 \mathrm{mg} / \mathrm{ml} \pm 0.04$ in ethanolic leaf extract (Table 3). Hydrogen peroxide $\left(\mathrm{H}_{2} \mathrm{O}_{2}\right)$ inactivates directly some important enzymes of cellular components mainly by the oxidation of essential thiol $(-\mathrm{SH})$ groups as $\mathrm{H}_{2} \mathrm{O}_{2}$ itself is a week oxidizing agent. Inside the cells, $\mathrm{H}_{2} \mathrm{O}_{2}$ can cross the membranes of the cells and interact mainly with $\mathrm{Fe}^{2+}$ ions and feasibly $\mathrm{Cu}^{2+}$ ions giving rise to hydroxyl free radicals which exhibits highly lethal impacts. ${ }^{63}$ Thus sequestration of excess $\mathrm{H}_{2} \mathrm{O}_{2}$ from cellular components is of great importance for the endogenous antioxidant defense system. A significant dose-dependent $\mathrm{H}_{2} \mathrm{O}_{2}$ scavenging potential of methanolic and ethanolic leaf extract of wild and cultivated chicory were observed during the present study. Further, the result also indicates that the methanolic leaf extract of both wild and cultivated chicory possesses higher scavenging activity with low $\mathrm{IC}_{50}$ value. The electron donors might accelerate the conversion of $\mathrm{H}_{2} \mathrm{O}_{2}$ to $\mathrm{H}_{2} \mathrm{O}^{64}$ which could possibly scavenge $\mathrm{H}_{2} \mathrm{O}_{2}$ in the methanolic leaf extract of chicory. The present study also described that wild chicory was found to be more effective than the cultivated chicory in scavenging $\mathrm{H}_{2} \mathrm{O}_{2}$ in both the extracts. Thus, the scavenging activity of the plant extracts might be due to their phenolic content that acts as reducing agent converting $\mathrm{H}_{2} \mathrm{O}_{2}$ to $\mathrm{H}_{2} \mathrm{O}$ inside the cell system. ${ }^{65}$

\section{Mineral element analysis}

Wild and cultivated chicory leaves was analysed in the present work for the presence of mineral elements by AAS technique. The result from the analysis shows that both wild and cultivated leaf extract of chicory contains various mineral elements like $\mathrm{Ca}, \mathrm{Fe}, \mathrm{Al}, \mathrm{Mn}, \mathrm{Zn}, \mathrm{Ni}, \mathrm{Cd}, \mathrm{Cu}$, $\mathrm{Pb}$, Co and $\mathrm{Cr}$ in different proportions (Table 4). It is important to be noted that each result is an average of at least three independent values. It is also evident from the results that leaf extract of wild chicory contains higher concentration of $\mathrm{Ca}(29876 \pm 20.00)$ and $\mathrm{Fe}(1478 \pm 15.75)$ followed by $\mathrm{Al}, \mathrm{Mn}, \mathrm{Zn}, \mathrm{Ni}, \mathrm{Cd}, \mathrm{Cu}, \mathrm{Pb}, \mathrm{Co}$ and $\mathrm{Cr}$ as compared to leaf extract of cultivated chicory respectively. However, $\mathrm{Ni}, \mathrm{Cd}, \mathrm{Pb}$ are toxic elements and occurs naturally in plants as a result of uptake mainly in places with high concentration due to atmospheric fallout. These are found in lower levels in both wild and cultivated chicory. The presence of mineral elements supports the ethnomedicinal uses of the plants. Traditional people use different plants for medicinal purposes as these plants possesses a high content of nutrient elements and other metabolites that are used to cure particular disease/disorder. However, the difference in the mineral and metabolite content in plants depends upon various parameters such as, type of cultivar, edaphic factors and other environmental conditions. ${ }^{66} \mathrm{Ca}$ in general plays a vital role in the formation of bones, teeth, muscle system and heart function. ${ }^{67} \mathrm{Fe}$ is also very important mineral for preventing anemia cough associated with angiotensinconverting enzyme (ACE) inhibitors and for the normal functioning of the central nervous system. ${ }^{68}$ Manganese helps the body to metabolize protein and carbohydrates and also plays a significant role in treating diabetes. ${ }^{69}$ It is important for the growth and multiplication of cells (enzymes responsible for DNA and RNA synthesis) for skin integrity and bone metabolism..$^{70}$ Deficiency of $\mathrm{Zn}$ results in growth retardation, hair loss, delayed wound healing and mental disturbances. ${ }^{71} \mathrm{Co}$ is necessary for vitamin $\mathrm{B}_{12}$ and thyroid metabolism. ${ }^{72}$ Deficiency of $\mathrm{Cr}$ results in insulin resistance, impair in glucose tolerance. Thus presence of these mineral elements in chicory leaves supports the traditional medicinal usage of this plant.

\section{GC-MS analysis}

From the present study, it has been found that the methanolic leaf extract of wild chicory exhibits higher antioxidant potential, possesses high concentration of mineral elements and phytochemicals which together suggests the importance of this plant as a source of bioactive compounds for various pharmaceutical applications. Keeping in-view the above 
Table 5: Bioactive compounds identified in the methanolic leaf extract of wild chicory by GC-MS.

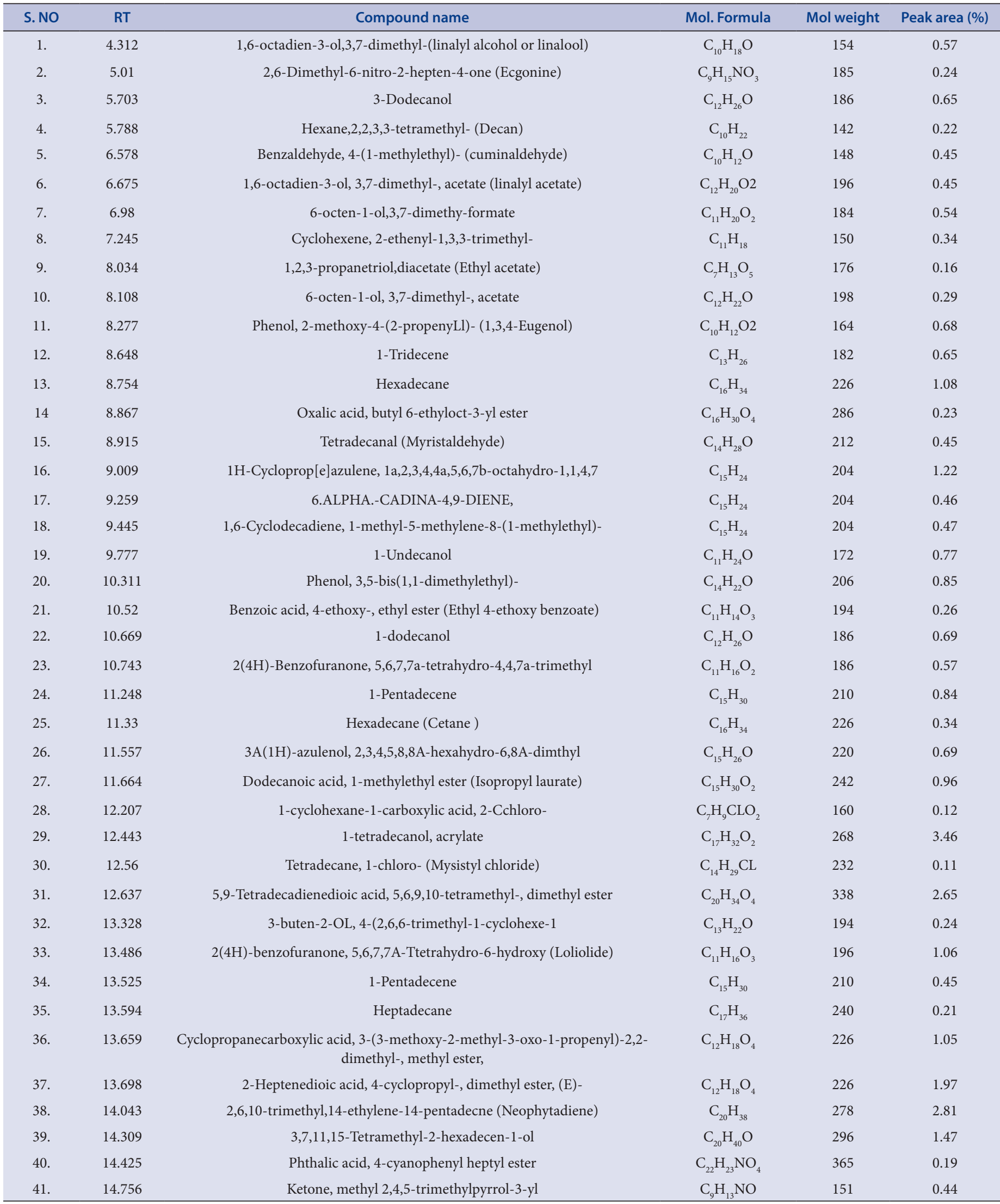




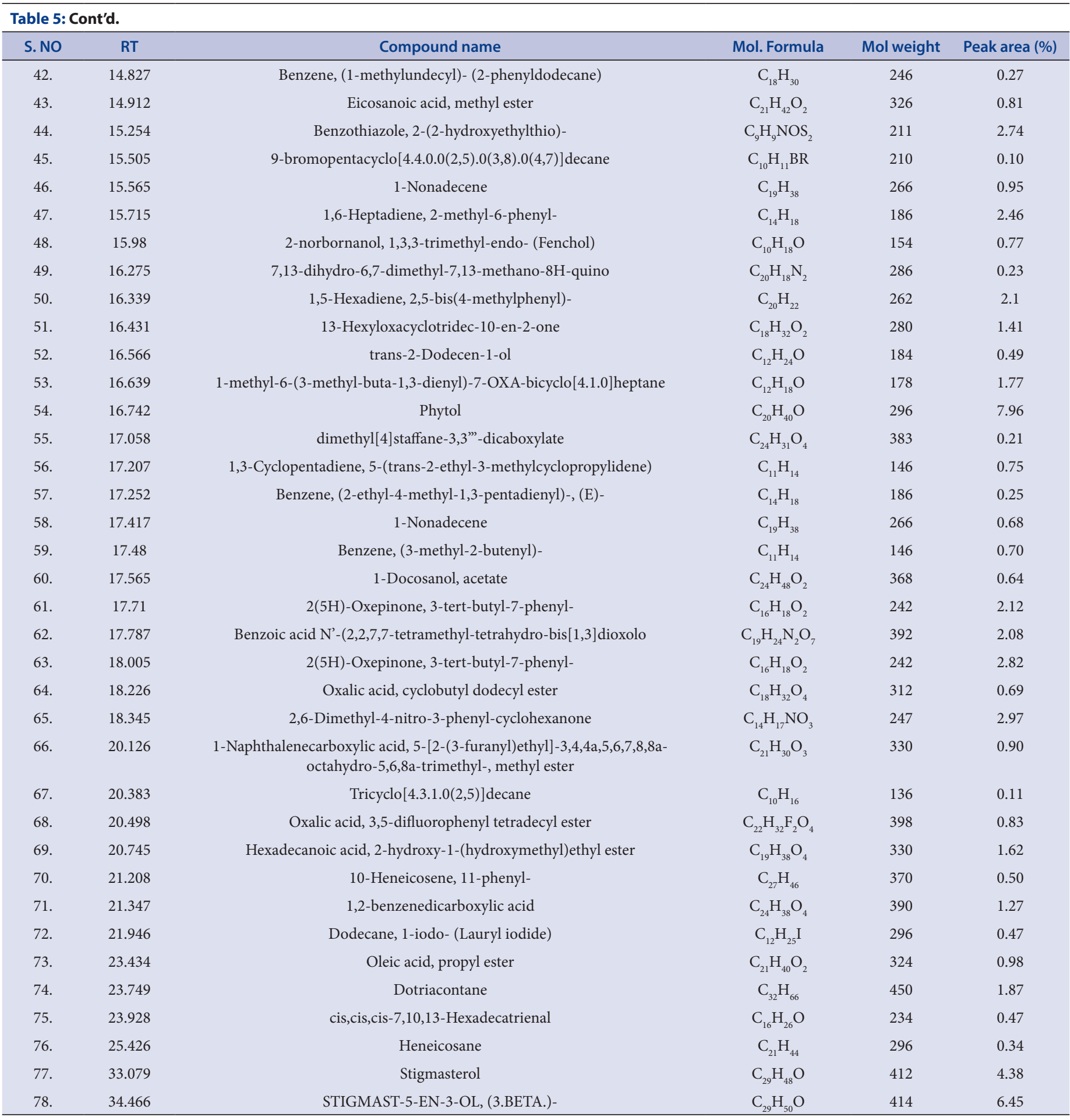

mentioned facts, the quantitative phytochemical analysis of the methanolic leaf extract of wild chicory was carried out by using GC-MS analysis method. In the present study, the result of the GC-MS analysis reveals the presence of 78 compounds from the methanolic leaf extract of chicory (Table 5). These compounds were identified through mass spectrometry attached with GC. The Total Ion Chromatogram (TIC) of the GC-MS analysis confirms the presence of several compounds and their different retention time is given in Figure 3. The major metabolites $(>2 \%)$ identified from the leaves of chicory in terms of percent area are phytol (7.96), Stigmast-5-en-3-ol, (3.BETA.)- (6.45), 1-tetradecanol, acrylate (3.46),
1,6-Heptadiene, 2-methyl-6-phenyl-(3.45),2,6-Dimethyl-4-nitro-3-phenyl-cyclohexanone (2.97), 2(5H)-Oxepinone, 3-tert-butyl-7-phenyl(2.82), 2,6,10-trimethyl,14-ethylene-14-pentadecnes (2.81), Benzothiazole, 2-(2-hydroxyethylthio)- (2.74), 9-Tetradecadienedioic acid, 5,6,9,10tetramethyl-, dimethyl ester (2.65). Among the compounds, phytol was found to be the major metabolite which is having Antimicrobial, Anticancer, Diuretic Anti-inflammatory properties followed by Stigmast5-en-3-ol, (3.BETA.)- having cholesterol lowering property, anti-cancer and antioxidant activities. The individual chromatogram of phytol and Stigmast-5-en-3-ol, (3.BETA.) is depicted in Figure 4a,b. Identification 


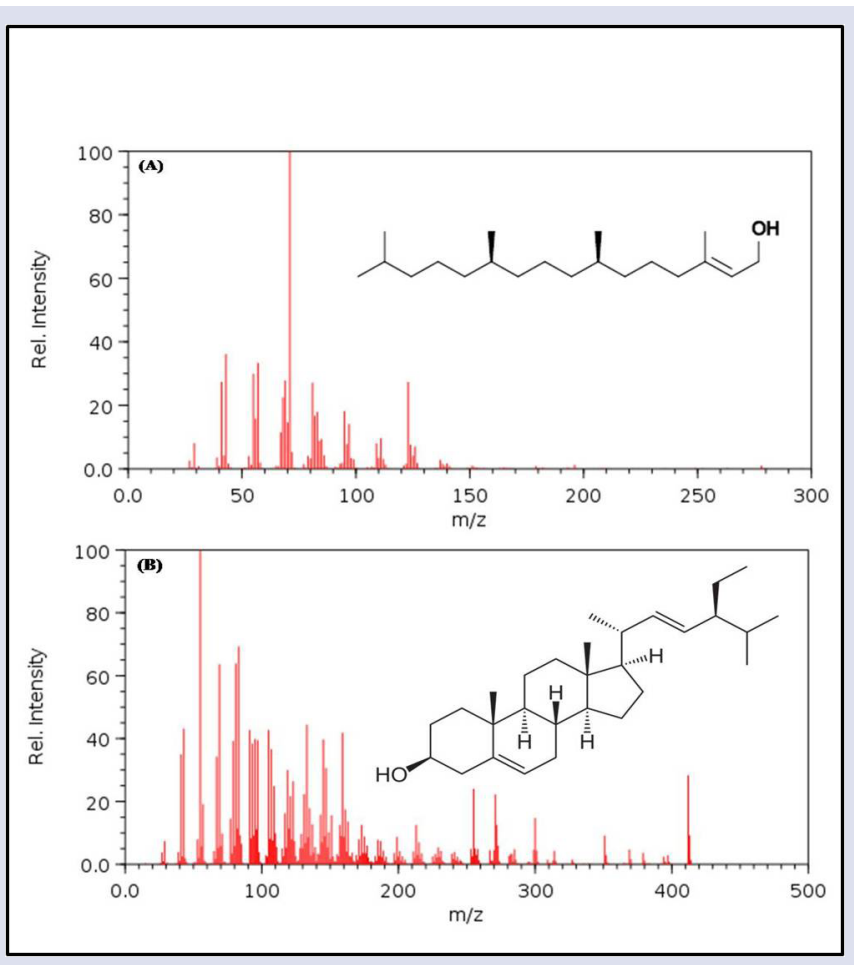

Figure 4: Shows the individual chromatogram of two major metabolites in terms of percent area (a) Phytol and (b) Stigmasterol.

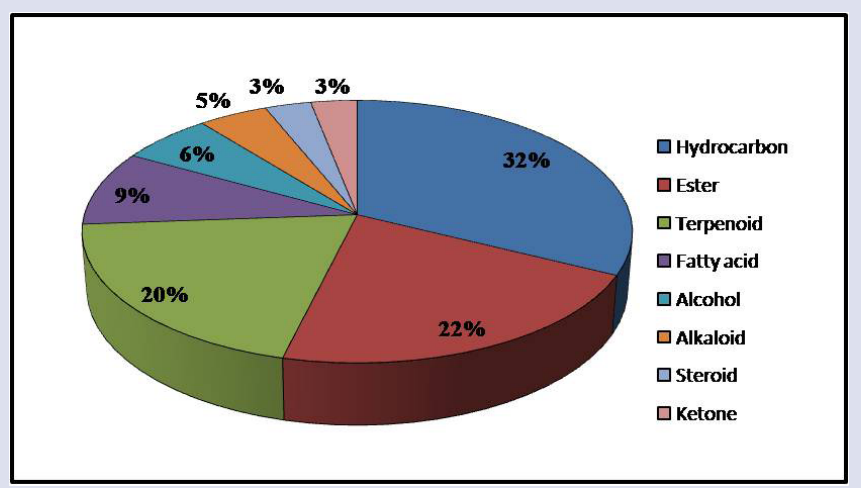

Figure 5: Major phytochemical groups present in the methanolic leaf extract of wild chicory.

of the compounds was done by using NIST library database and their activities listed are based on Dr. Duke's phytochemical and ethno-botanical database by Dr. Jim Duke Agriculture Research Science/USDA. The present study from the GC-MS analysis revealed the presence of 98 compounds from the methanolic leaf extract of chicory. The prediction of the biological activities by using the Duke's databases confirmed that the chicory exhibits tremendous pharmaceutical properties, as some of the bioactive compounds identified from GC-MS analysis possess potent therapeutic applications (Table 6). The major compounds present in the extracts were in the order of hydrocarbons $>$ esters $>$ terpenoids $>$ fatty acids $>$ alkaloids $>$ alcohols $>$ steroids $>$ ketones (Figure 5). Other phytochemicals have been shown to possess anticancer, antibacterial, antimicrobial, antiseptic, insecticidal activities. ${ }^{73}$ GC-MS analysis from different plants also confirmed several pharmacological properties which are in accordance with our study. ${ }^{74,75}$ Currently, there is an increase in awareness of correlating the bioactive constituents with their biological activities. ${ }^{76}$ Thus from the GC-MS analysis chicory from Kashmir Himalaya can be utilized as an important sources of bioactive compounds for various pharmaceutical and neutraceutical applications.

\section{CONCLUSION}

Chicory is a medicinal plant used in traditional system of medicines however there are no reports on the antioxidant potential and phytochemical analysis of the plant from the Kashmir Himalaya. The finding of the present study indicates that the wild chicory could be a good source of natural antioxidants that might have a high possible significance as remedial agent in inhibiting or slowing down oxidative stress related diseases. Methanolic leaf extract of wild chicory exhibited highest activities suggesting methanol as an optimal solvent for phytochemical extraction. Powerful antioxidant ability of the plant extracts for various in-vitro antioxidant assays may be attributed due to the occurrence of antioxidant compounds in this plant such as phenols, flavonoids, alkaloids, tannins, coumarins, terpenoids etc. The data obtained from the elemental analysis shows that chicory contains elements of vital importance that have immense application in preventing and treatment of various diseases. Here, we also report the presence of very important bioactive compounds and their biological activities which if appropriately and comprehensively investigated, could furnish various chemically important and biologically operative drug molecules, which includes few anti-proliferative characteristics. Thus, this study is the first step towards understanding the nature of the bioactive compounds in this medicinal plant and further investigations will lead to the development of new drug formulations.

\section{ACKNOWLEDGEMENT}

RUR is thankful of University of Kashmir (UofK) for providing the Seed Grant. Thanks to the staff at University Science and Instrumentation Centre (USIC, UofK) for elemental analysis.

\section{CONFLICT OF INTEREST}

The authors declare that there is no conflict of interest with any party.

\section{ABBREVIATION USED}

ROS: Reactive oxygen species; BHT: Butylated hydroxytoluene; DPPH: 2, 2-diphenyl-1-picrylhydrazyl; EDTA: Ethylenediamine tetracetic acid; IC: Inhibition concentration; FRAP: Ferric Reducing Antioxidant Potential; GC-MS: Gas chromatography-mass spectrometry; NADH: Nicotinamide adenine dinucleotide; NBT: Nitro blue tetrazolium; NIST: National Institute of Standards and Technology; PMS: Phenazine methosulphate; SOD: Superoxide radical; TBA: Thiobarbituric acid; TPC: Total phenol content; TFC: Total flavonoid content; TPTZ: 2,4,6-tripyridyl-s-triazine.

\section{REFERENCES}

1. Thomson MJ. The role of free radicals and antioxidants. Crit Rev Food Sci Nutr. 1995;35:21-29.

2. Lee KG, Mitchell AE, Shibamoto T. Determination of antioxidant properties of aroma extracts from various beans. Journal of Agricultural and Food Chemistry. 2000;48(10):4817-20

3. Kris-Etherton PM, Hecker KD, Bonanome A, Coval SM, Binkoski AE, Hilpert KF et al. Bioactive compounds in foods: their role in the prevention of cardiovascular disease and cancer. The American Journal of Medicine. 2002;113(9):71-88.

4. Niki E. Assessment of antioxidant capacity in vitro and in vivo. Free Radic Biol Med. 2010;49:503-05.

5. Karimi E, Oskoueian E, Hendra R, Jaafar HZ. Evaluation of Crocus sativus L. stigma phenolic and flavonoid compounds and its antioxidant activity. Molecules. 2010;15(9):6244-56

6. Gülçin I, Topal F, Çakmakçı R, Bilsel M, Gören AC, Erdogan U. Pomological features, nutritional quality, polyphenol content analysis, and antioxidant properties 
of domesticated and 3 wild ecotype forms of raspberries (Rubus idaeus L.). Journal of Food Science. 2011;76(4)

7. Brussels. Third United Nations Conference on the least developed countries profile, Medicinal Plants. 2001; Pp: 2

8. Gulcin I, Beydemir S. Phenolic compounds as antioxidants: carbonic anhydrase isoenzymes inhibitors. Mini Reviews in Medicinal Chemistry. 2013;13(3):40830.

9. Bursal E, Köksal E, Gülçin I, Bilsel G, Gören AC. Antioxidant activity and polyphenol content of cherry stem (Cerasus avium L.) determined by LC-MS/ MS. Food Research International. 2013;51(1):66-74.

10. Scholz E. Monographien: Cichorium, Cichorium intybus L., Cichorii folia et radix, Cichorii radix. In Hagers Handbuch der Drogen und Arzneistoffe, Hager ROM, Eds WE, Blaschek S, Ebel E, Hackental U, Holzgrabe K, Keller J, Reichling J, Schulz. Springer Medizin Verlag Heidelberg (2006).

11. Blumenthal M. The complete German Commission E monographs. American Botanical Council, Austin TX 109 (1998).

12. Vilkhu K, Mawson R, Simons L, Bates D. Applications and opportunities for ultrasound assisted extraction in the food industry-A review. Innovative Food Science \& Emerging Technologies. 2008;9(2):161-9.

13. Poletti AH, Schilcher Müller A. In Heilkraftige Pflanzen, Walter Hadecke Verlag 1989:171.

14. Hazra B, Sarkar R, Bhattacharyya S, Roy P. Tumour inhibitory activity of chicory root extract against Ehrlich ascites carcinoma in mice. Fitoterapia. 2002;73(7):730-3.

15. Bischoff TA, Kelley CJ, Karchesy Y, Laurantos M, Nguyen-Dinh P, Arefi AG. Antimalarial activity of Lactucin and Lactucopicrin: sesquiterpene lactones isolated from Cichorium intybus L. Journal of Ethnopharmacology. 2004;95(2):455-7.

16. Pushparaj PN, Low HK, Manikandan J, Tan BK, Tan CH. Anti-diabetic effects of Cichorium intybus in streptozotocin-induced diabetic rats. Journal of Ethnopharmacology. 2007;111(2):430-4.

17. Lante A, Nardi T, Zocca F, Giacomini A, Corich V. Evaluation of red chicory extract as a natural antioxidant by pure lipid oxidation and yeast oxidative stress response as model systems. Journal of Agricultural and Food Chemistry. 2011;59(10):5318-24

18. Bais HP, Ravishankar GA. Cichorium intybus L-cultivation, processing, utility, value addition and biotechnology, with an emphasis on current status and future prospects. Journal of the Science of Food and Agriculture. 2001;81(5):467-84

19. Sun LY, Touraud G, Charbonnier C, Tepfer D. Modification of phenotype in Belgian endive (Cichorium intybus) through genetic transformation byAgrobacterium rhizogenes: conversion from biennial to annual flowering. Transgenic Research. 1991:1(1):14-22.

20. Demigné C, Jacobs H, Moundras C, Davicco MJ, Horcajada MN, Bernalier A et al. Comparison of native or reformulated chicory fructans, or non-purified chicory, on rat cecal fermentation and mineral metabolism. European Journal of Nutrition. 2008;47(7):366-74

21. Sinkovic L, Hribar J, Vidrih R. Influence of Cultivar and Storage of Chicory (Cichorium intybus L.) Plants on Polyphenol Composition and Antioxidative Potential. Czech Journal of Food Science. 2014;32(1):10-15

22. Okogun JI. Methods of Medicinal Plant Extract Preparation. National Institute for Pharmaceutical Research and Development (NIIPRD) Idu - Abuja. Nigeria 2000.

23. Shabbir M, Khan MR, Saeed N. Assessment of phytochemicals, antioxidant, anti-lipid peroxidation and anti-hemolytic activity of extract and various fractions of Maytenus royleanus leaves. BMC Complementary and Alternative Medicine. 2013;13(1):143.

24. Kim DO, Jeong SW, Lee CY. Antioxidant capacity of phenolic phytochemicals from various cultivars of plums. Food Chemistry. 2003;81(3):321-6.

25. Sakanaka S, Tachibana Y, Okada Y. Preparation and antioxidant properties of extracts of Japanese persimmon leaf tea (kakinoha-cha). Food Chemistry. 2005;89(4):569-75.

26. Yen GC, Duh PD. Antioxidative properties of methanolic extracts from peanut hulls. Journal of the American Oil Chemists' Society. 1993;70(4):383-6.

27. Benzie IF, Strain JJ. The ferric reducing ability of plasma (FRAP) as a measure of "antioxidant power": the FRAP assay. Analytical Biochemistry. 19965;239(1):70-6.

28. Braca A, Fico G, Morelli I, De Simone F, Tomè F, De Tommasi N. Antioxidant and free radical scavenging activity of flavonol glycosides from different Aconitum species. Journal of Ethnopharmacology. 2003;86(1):63-7.

29. Fontana M, Mosca L, Rosei MA. Interaction of enkephalins with oxyradicals. Biochemical Pharmacology. 2001 May 15;61(10):1253-7.

30. Nabavi SM, Ebrahimzadeh MA, Nabavi SF, Hamidinia A, Bekhradnia AR. Determination of antioxidant activity, phenol and flavonoids content of Parrotia persica Mey. Pharmacologyonline. 2008;2:560-7.

31. Mostofa MG, Hossain MA, Fujita M, Tran LS. Physiological and biochemical mechanisms associated with trehalose-induced copper-stress tolerance in rice. Scientific Reports. 2015;5:11433

32. Roessner U, Wagner C, Kopka J, Trethewey RN, Willmitzer L. Simultaneous analysis of metabolites in potato tuber by gas chromatography-mass spectrometry. The Plant Journal. 2000;23(1):131-42.

33. Lako J, Trenerry VC, Wahlqvist M, Wattanapenpaiboon N, Sotheeswaran S,
Premier R. Phytochemical flavonols, carotenoids and the antioxidant properties of a wide selection of Fijian fruit, vegetables and other readily available foods. Food Chemistry. 2007;101(4):1727-41.

34. Nair R, KALARIYA T, Chanda S. Antibacterial activity of some selected Indian medicinal flora. Turkish Journal of Biology. 2005;29(1):41-7.

35. Zhang L, Ravipati AS, Koyyalamudi SR, Jeong SC, Reddy N, Smith PT, Bartlett J, Shanmugam K, Münch G, Wu MJ. Antioxidant and anti-inflammatory activities of selected medicinal plants containing phenolic and flavonoid compounds. Journal of Agricultural and Food Chemistry. 2011;59(23):12361-7.

36. Liu H, Qiu N, Ding H, Yao R. Polyphenols contents and antioxidant capacity of 68 Chinese herbals suitable for medical or food uses. Food Research International. 2008; 41(4):363-70

37. Alghazeer R, El-Saltani H, Saleh N, Al-Najjar A, Hebail F. Antioxidant and antimicrobial properties of five medicinal Libyan plants extracts. Natural Science. 2012;4(5):324

38. Atanassova M, Georgieva S, Ivancheva K. Total phenolic and total flavonoid contents, antioxidant capacity and biological contaminants in medicinal herbs. J Chem Technol Metall 2011;46(1):81-8.

39. Shahidi F, Wanasundara KJ. Critical revievs in food science. Nutrition 1992;32(1):67.

40. Michalak A. Phenolic compounds and their antioxidant activity in plants growing under heavy metal stress. Polish Journal of Environmental Studies. 2006;15(4).

41. Pai TV, Sawant SY, Ghatak AA, Chaturvedi PA, Gupte AM, Desai NS. Characterization of Indian beers: chemical composition and antioxidant potential. Journal of Food Science and Technology. 2015;52(3):1414-23.

42. Sahreen S, Khan MR, Khan RA. Evaluation of antioxidant activities of various solvent extracts of Carissa opaca fruits. Food Chemistry. 2010;122(4):1205-11.

43. Sahreen S, Khan MR, Khan RA. Phenolic compounds and antioxidant activities of Rumex hastatus D. Don. Leaves. Journal of Medicinal Plants Research. 2011; 5(13):2755-65.

44. Bisma M, Neeta R, Giridhar S. Influence of agro-climatic conditions on antioxidant potential of Mentha species. J Pharma Res. 2013;7:427-32.

45. Tsimogiannis DI, Oreopoulou V. The contribution of flavonoid C-ring on the DPPH free radical scavenging efficiency. A kinetic approach for the $3^{\prime}$ 4'-hydroxy substituted members. Innovative Food Science \& Emerging Technologies. 2006;7(1):140-6.

46. Zunjar V, Mammen D, Trivedi BM. Antioxidant activities and phenolics profiling of different parts of Carica papaya by LCMS-MS. Natural Product Research. 2015;29(22):2097-9.

47. Pantelidis GE, Vasilakakis M, Manganaris GA, Diamantidis GR. Antioxidant capacity, phenol, anthocyanin and ascorbic acid contents in raspberries, blackberries, red currants, gooseberries and Cornelian cherries. Food Chemistry. 2007;102(3):777-83.

48. Bursal E, Gülçin I. Polyphenol contents and in vitro antioxidant activities of lyophilised aqueous extract of kiwifruit (Actinidia deliciosa). Food Research International. 2011;44(5):1482-9.

49. Umamaheswari M, Chatterjee TK. In vitro antioxidant activities of the fractions of Coccinia grandis L. leaf extract. African Journal of Traditional, Complementary and Alternative Medicines. 2008;5(1):61-73.

50. Ganu GP, Jadhav SS, Deshpande AD. Antioxidant and antihyperglycemic potential of methanolic extract of bark of mimusops elengi I. In mice. International Journal of Phytomedicine. 2010;2(2):67-77.

51. Kavimani S, Saminathan K, Senthil SK. Antioxidant and free radical scavenging activities of Dolichandrone atrovirens using various in vitro assay models. Int J Phytopharmacol. 2014;5(4):293-300.

52. Yildiz H, Ercisli S, Hegedus A, Akbulut M, Topdas EF, Aliman J. Bioactive content and antioxidant characteristics of wild (Fragaria vesca L.) and cultivated strawberry (Fragariax ananassa Duch.) fruits from Turkey. Journal of Applied Botany and Food Quality. 2014;87(1):274-8.

53. Duh PD, Du PC, Yen GC. Action of methanolic extract of mung bean hulls as inhibitors of lipid peroxidation and non-lipid oxidative damage. Food and Chemical Toxicology. 1999;37(11):1055-61.

54. Alam MN, Bristi NJ, Rafiquzzaman M. Review on in vivo and in vitro methods evaluation of antioxidant activity. Saudi Pharmaceutical Journal. 2013;21(2):143-52

55. Rabeta MS, Nur FR. Total phenolic content and ferric reducing antioxidant power of the leaves and fruits of Garcinia atrovirdis and Cynometra cauliflor. Int Food Res J. 2013;20(4):1691-6.

56. Bursal E, Köksal E. Evaluation of reducing power and radical scavenging activities of water and ethanol extracts from sumac (Rhus coriaria L.). Food Research International. 2011;44(7):2217-21.

57. Aparadh VT, Naik VV, Karadge BA. Antioxidative properties (TPC, DPPH, FRAP, metal chelating ability, reducing power and TAC) within some Cleome species. Annali di Botanica. 2012;2:49-56.

58. Sre PR, Sheila T, Murugesan K. Phytochemical screening and "in-vitro" antioxidant activity of methanolic root extract of Erythrina indica. Asian Pacific Journal of Tropical Biomedicine. 2012;2(3):S1696-700.

59. Jaradat NA, Abualhasan M, Ali I. Comparison of Anti-Oxidant Activities and 
Exhaustive Extraction Yields between Wild and Cultivated Cyclamen persicum, Malva sylvestris and Urtica pilulifera Leaves.

60. Choi CW, Kim SC, Hwang SS, Choi BK, Ahn HJ, Lee MY, et al. Antioxidant activity and free radical scavenging capacity between Korean medicinal plants and flavonoids by assay-guided comparison. Plant Science. 2002;163(6):1161-8.

61. Blois MS. Antioxidant determinations by the use of a stable free radical. Nature. 1958;181(4617):1199-200.

62. Bora KS, Sharma A. In vitro antioxidant and free radical scavenging potential of Medicago sativa Linn. J Pharma Res. 2010;3(6):1206-10.

63. Kumaran A, Karunakaran RJ. In vitro antioxidant activities of methanol extracts of five Phyllanthus species from India. LWT-Food Science and Technology. 2007; 40(2):344-52.

64. Ruch RJ, Cheng SJ, Klaunig JE. Prevention of cytotoxicity and inhibition of intercellular communication by antioxidant catechins isolated from Chinese green tea. Carcinogenesis. 1989;10(6):1003-8.

65. Banerjee SK, Bonde CG. Total phenolic content and antioxidant activity of extracts of Bridelia retusa Spreng Bark: Impact of dielectric constant and geographical location. J Med Plants Res. 2011;5(5):817-22.

66. Rajurkar NS, Pardeshi BM. Analysis of some herbal plants from India used in the control of diabetes mellitus by NAA and AAS techniques. Appl Radiat and Isot. 1997;48:1059.

67. Brody T. Nutritional Biochemistry, San Diego Academic Press. 1994.
68. Adeyeyei El, Otokiti MK. Proximate Composition and Some Nutritionally Valuable Minerals of Two Varieties of Capsicum annumL.(Bell and Cherry Peppers). Discovery and Innovation. 1999:11(1):75-82.

69. Weber $\mathrm{G}$, Konieczynski P. Speciation of $\mathrm{Mg}, \mathrm{Mn}$ and $\mathrm{Zn}$ in extracts of medicinal plants. Analytical and Bioanalytical Chemistry. 2003;375(8):1067-73.

70. Thunus L, Lejeune R. In: Seiler HG, Sigel A, Sigel H. Handbook on Metals in Clinical and Analytical Chemistry, Marcel Dekker, New York brazil (eds.) 1994;333.

71. Khan KY, Khan MA, Niamat R, Munir M, Mazari HF, Seema N, Bashir T, Kanwal A, Ahmed SN. Element content analysis of plants of genus Ficus using atomic absorption spectrometer. African Journal of Pharmacy and Pharmacology. 2011;5(3):317-21

72. Rajurkar NS, Damame MM. Mineral content of medicinal plants used in the treatment of diseases resulting from urinary tract disorders. Applied Radiation and Isotopes. 1998;49(7):773-6.

73. Online: Available from: http://www.ars-grin.gov/duke/.

74. Hema R, Kumaravel S, Alagusundaram K. GC-MS Study on the bioactive components and anti-cancer activities of Solanum surattense. Cancer Biol. 2011;1(1):13-7.

75. Ezhilan B, Neelamegam R. GC-MS Determination of Bioactive Compounds of Polygonum glabrum (Wild). Journal of Phytology. 2011;3(9).

76. Fernie AR, Trethewey RN, Krotzky AJ, Willmitzer L. Metabolite profiling: from diagnostics to systems biology. Nature reviews. Molecular Cell Biology. 2004;5(9):763

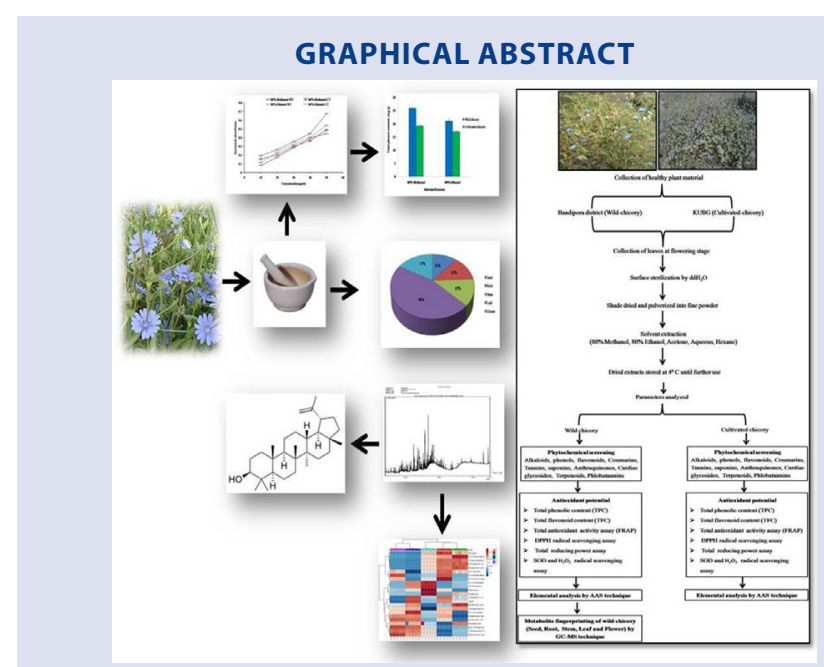

\section{SUMMARY}

- Qualitative phytochemical screening revealed various metabolites in the Methanolic leaf extract of wild chicory.

- Chicory possess potent antioxidant properties thus could replace synthetic antioxidants.

- GC-MS profiling of leaf sample revealed important secondary metabolites, thus specifies its significant role in the functional food sector.

- Ionomic analysis revealed important macro-and micro-nutrients thus can be used as a potent biofortified crop.

\section{ABOUT AUTHORS}

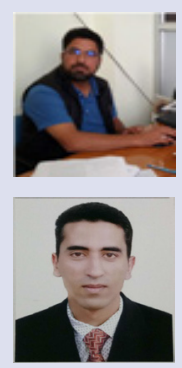

Dr. Reiaz UI Rehman: Is currently working as an Assistant Professor, Department of Bioresources, University of Kashmir, Srinagar, India. He was awarded PhD (plant biotechnology) in 2003 by Jamia Hamdard, New Delhi. Dr. Reiaz ul Rehman has about 14 years of teaching/research experience in plant biology. He is a recipient of several fellowships at both national and international level, particularly, the award of the Marie Curie IIF project (MC-IIF-FP7-219339). He has to his credit one published book and 22 publications in various national and international journals.

Tanveer Bilal Pirzadah: Is a PhD research scholar in the Department of Bioresources, University of Kashmir. He has worked on proteomics and stress biology in buckwheat, which is relevant to economical aspect in terms of crop productivity. He has to his credit 10 publications in interna-tional journals and 18 book chapters published by Springer and Elsevier publications. He has been awarded the Certificate from Elsevier Publishers, Netherland for his article among top 25 hottest articles on Science Direct (EEB) for three months (Third Rank).

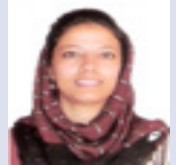

Bisma Malik: Is a PhD scholar in the Department of Bioresources, University of Kashmir. She has worked on proteomics and stress biology in chicory-an untapped Bioresource from Kashmir Himalaya. She has to his credit 5 publications in international journals and 18 book chapters published by Springer and Elsevier publications. She is the recipient of Women scientist (WOS-A) fellow from DST, India.

Dr. Inayatullah Tahir: Is currently working as a Professor, Department of Botany, University of Kashmir, Srinagar, India. He earned his PhD degree in botany from Kashmir University in 1986. Prof. Inayatullah Tahir has more than 28 years of teaching and research experience. He has done extensive work pertaining to physiological studies on buckwheats in Kashmir. Buckwheat belonging to genus Fagopyrum is an important bioresource in view of its historical perspective and socio-economic benefits. He has also been actively perusing the research on flower senescence and postharvest physiology of the ornamentals. He has published more than 60 papers in various national and international journals. He has attended and presented his research findings in various national and international conferences; besides, he is life member of several learned scientific societies.

Cite this article: Malik B, Pirzadah TB, Tahir I, Rehman RU. Chemo-profiling, Antioxidant potential and lonomic analysis of Cichorium intybus L. Pharmacog J. 2017;9(6):917-28. 